Nova Southeastern University

Florida

NOVA SOUTHEASTERN

UNIVERSTYY

NSUWorks

Marine \& Environmental Sciences Faculty Articles Department of Marine and Environmental Sciences

2-9-2004

\title{
New Species of Eustomias (Teleostei: Stomiidae) from the Western North Atlantic, with a Review of the Subgenus Neostomias
}

Tracey Sutton

Harbor Branch Oceanographic Institution, tsutton1@nova.edu

Karsten E. Hartel

Harvard University

Find out more information about Nova Southeastern University and the Halmos College of Natural Sciences and Oceanography.

Follow this and additional works at: https://nsuworks.nova.edu/occ_facarticles

Part of the Marine Biology Commons, and the Oceanography and Atmospheric Sciences and Meteorology Commons

\section{NSUWorks Citation}

Tracey Sutton and Karsten E. Hartel. 2004. New Species of Eustomias (Teleostei: Stomiidae) from the Western North Atlantic, with a Review of the Subgenus Neostomias .Copeia , (1): 116 -121.https://nsuworks.nova.edu/occ_facarticles/531.

This Article is brought to you for free and open access by the Department of Marine and Environmental Sciences at NSUWorks. It has been accepted for inclusion in Marine \& Environmental Sciences Faculty Articles by an authorized administrator of NSUWorks. For more information, please contact nsuworks@nova.edu. 


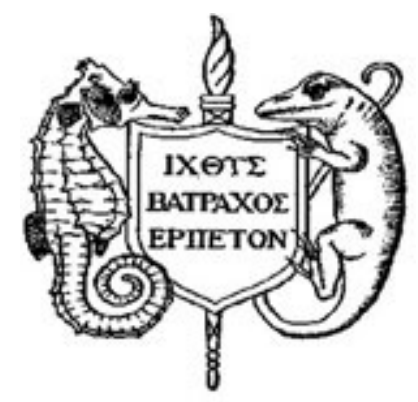

New Species of Eustomias (Teleostei: Stomiidae) from the Western North Atlantic, with a Review of the Subgenus Neostomias

Author(s): Tracey T. Sutton and Karsten E. Hartel

Source: Copeia, Vol. 2004, No. 1 (Feb. 9, 2004), pp. 116-121

Published by: American Society of Ichthyologists and Herpetologists (ASIH)

Stable URL: http://www.jstor.org/stable/1448645

Accessed: 27-05-2015 16:45 UTC

\section{REFERENCES}

Linked references are available on JSTOR for this article:

http://www.jstor.org/stable/1448645?seq=1\&cid=pdf-reference\#references_tab_contents

You may need to log in to JSTOR to access the linked references.

Your use of the JSTOR archive indicates your acceptance of the Terms \& Conditions of Use, available at http://www.jstor.org/page/ info/about/policies/terms.jsp

JSTOR is a not-for-profit service that helps scholars, researchers, and students discover, use, and build upon a wide range of content in a trusted digital archive. We use information technology and tools to increase productivity and facilitate new forms of scholarship. For more information about JSTOR, please contact support@jstor.org. 


\title{
New Species of Eustomias (Teleostei: Stomiidae) from the Western North Atlantic, with a Review of the Subgenus Neostomias
}

\author{
Tracey T. Sutton and Karsten E. Hartel
}

\begin{abstract}
A new species of the deep-sea dragonfish genus Eustomias is described from 14 specimens from the western North Atlantic. This species belongs to the subgenus Neostomias, which is defined principally by the presence of a single pectoral ray, plus one small rudimentary ray. It is unique among members of the subgenus in having a combination of characters that includes a short mental barbel, multiple proximal bulbs on the barbel main stem, and a unique terminal bulb morphology. Analysis of similar species warrants resurrection of Eustomias monodactylus, previously placed in synonymy with Eustomias filifer. A revised key to the species of the subgenus Neostomias is provided.
\end{abstract}

$\mathrm{T}^{\mathrm{H}}$ HE genus Eustomias Vaillant is extremely species-rich, but specimens are rare in collections, the majority of the species known from only one or two specimens. Apart from differences in the number of pectoral rays, the vast majority of species are distinguished solely on the mental barbel (barbel hereafter). Indeed, of the 115 species known to date, only two, Eustomias obscurus and Eustomias parri, can be accurately identified to species sans barbel. The existence of only one or two specimens per species precludes an understanding of the variability of barbel morphology, which has lead to uncertainty regarding the validity of many described species (Gibbs, 1986).

A single specimen of Eustomias, collected on a recent NOAA Ocean Exploration Deepwater Systematics cruise in the western North Atlantic Ocean, was easily assigned to the subgenus Neostomias but did not fit any recognized species. Examination of Neostomias in the Museum of Comparative Zoology, Harvard University (MCZ), and the Division of Fishes, National Museum of Natural History, Smithsonian Institution (USNM), resulted in the discovery of 13 additional specimens of the new form. This examination revealed that barbel characteristics of the species treated herein are highly consistent, allowing for a review of the subgenus Neostomias and the description of this new species.

\section{MATERIALS AND METHODS}

Measurements, counts, photophore terminology, and barbel morphology follow Morrow and Gibbs (1964) and Gibbs et al. (1983). Measurements were made with dial calipers. Barbel measurements required manual manipulation, and ratios derived from these measurements should be interpreted conservatively. Tooth counts are total number, including replacement teeth. Ser- rate maxillary teeth, their number being a function of age, were not counted. Vertebral counts were made from radiographs. The barbel descriptions assume that the barbel trails posteriad with the branches on the dorsal side. The holotype was collected with a nonclosing International Young Gadoid Pelagic Trawl (IYGPT). Paratypes and comparative material were taken with the following gear: an IYGPT; a 3.3-m Isaacs-Kidd Midwater Trawl (IKMT); a large Engel midwater trawl (EMT; Gibbs and Karnella, 1987); a 1-m plankton net; a $10 \mathrm{~m}^{2}$ MOCNESS (MOC10); or a $20 \mathrm{~m}^{2}$ MOCNESS (MOC20). In the list of material examined, the sex, if known, and SL (millimeters) follow the specimen museum number in parentheses.

\section{Subgenus Neostomias Gilchrist, 1906}

Diagnosis.—Neostomias (sensu Gibbs et al., 1983) differs from other recognized subgenera of Eustomias in having seven pelvic-fin rays; one long and one rudimentary pectoral-fin ray; barbel with three branches of variable complexity arising together from main stem; stem beyond branches with one or more proximal bulbs and a terminal bulb; ventral body groove extending to PV 9-17; lateral photophores evenly spaced, not in pairs. We recognize four species, one of which is here described as new.

\section{Key to SPecies of The Subgenus Neostomias}

1A. Barbel with a single, well-defined proximal bulb on main stem between point of branching and terminal bulb

1B. Barbel with two or more discrete proximal bulbs on main stem, or two contiguous bulbs forming one long (20-25\% main stem length) irregular bulb, between point of branching and terminal bulb 
one or more branches reaching terminal bulb; terminal bulb less than four diameters from proximal bulb

\section{Eustomias (Neostomias) monodactylus}

Regan and Trewavas, 1930

2B. Barbel main stem length greater than $25 \% \mathrm{SL}$; no branches reaching terminal bulb; terminal bulb 6-17 diameters away from proximal bulb

Eustomias (Neostomias) filifer (Gilchrist, 1906)

3A. Barbel with three or more proximal bulbs on main stem between point of branching and terminal bulb; main stem beyond branches tapering to small, simple terminal bulb with no filaments

Eustomias (Neostomias) tetranema Zugmayer, 1913

3B. Barbel with two discrete or contiguous proximal bulbs on main stem between point of branching and terminal bulb; main stem beyond branches thickening to a large terminal bulb with two groups of filaments

Eustomias (Neostomias) jimcraddocki n. sp.

Eustomias jimcraddocki, n. sp. Figures 1A, 2A-B

Eustomias filifer. Gibbs, 1971:239-240, fig. 2 (in part).

Holotype-MCZ 162290 (ơ, $143.3 \mathrm{~mm} \mathrm{SL}$ ), NOAA R/V Delaware II, Station DL0206:051, western North Atlantic (over Munson Canyon), $40^{\circ} 20-22^{\prime} \mathrm{N}, 66^{\circ} 41-44^{\prime} \mathrm{W}, 31 \mathrm{Jul} 2002$, time at depth 0129-0229 hrs local time, depth of sampling 0-809 $\mathrm{m}$ (mainly at lower depth), water depth 2230-2483 m, IYGPT.

Paratypes.-MCZ $82661 \quad\left(0^{\circ}, 126\right), 40^{\circ} 10^{\prime} \mathrm{N}$ $65^{\circ} 00^{\prime} \mathrm{W}, 07$ September 1985, $3000 \mathrm{~m}$ wire out [mwo]. MCZ 153127 (?, 46), $33^{\circ} 26^{\prime} \mathrm{N} 67^{\circ} 23^{\prime} \mathrm{W}$, 05 November 1992, 1051-1212 h, 0-920 m, MOC10. MCZ 155482 (?, 63), $35^{\circ} 05^{\prime} \mathrm{N} 72^{\circ} 18^{\prime} \mathrm{W}$, 07 February 1999, IYGPT. MCZ 155487 (?, 3: $83-95), 35^{\circ} 04^{\prime} \mathrm{N} 72^{\circ} 09^{\prime} \mathrm{W}, 07$ February 1999 , 1000-1100 h, IYGPT. MCZ 155489 (\%, 112), $35^{\circ} 01^{\prime} \mathrm{N} 72^{\circ} 10^{\prime} \mathrm{W}, 07$ February $1999,0707-0807$ h, IYGPT. MCZ 162851 (o, 141), $38^{\circ} 39^{\prime} \mathrm{N}$ $72^{\circ} 05^{\prime} \mathrm{W}, 24$ September 1982, 1444-1514 h, 750-500 m, MOC20. MCZ 162852 (?, 78), $33^{\circ} 51^{\prime} \mathrm{N} 74^{\circ} 35^{\prime} \mathrm{W}, 23$ February 1979, 2109-2148 h, 200-100 m, MOC10. USNM 263076 (?, 92), $33^{\circ} 18^{\prime} \mathrm{N} 64^{\circ} 43^{\prime} \mathrm{W}$, 04 July 1968 , IKMT. USNM 263077 ( $\%, 132$ ), $32^{\circ} 22^{\prime} \mathrm{N} 64^{\circ} 04^{\prime} \mathrm{W}, 22$ August 1971, 2046-2207 h, 0-100 m, EMT. USNM 263079 ( $\widehat{\circ}, 124.1), 32^{\circ} 57^{\prime} \mathrm{N} 64^{\circ} 29^{\prime} \mathrm{W}, 03$ July 1968, 0-1931 m, IKMT. USNM 323066 (o, 124), $39^{\circ} 44^{\prime} \mathrm{N} 56^{\circ} 59^{\prime} \mathrm{W}, 01$ September $1979,0-200 \mathrm{~m}$.
Diagnosis.-A species of Eustomias with two pectoral rays (one as tiny rudiment), and a barbel with three branches arising proximal to midlength of the stem, followed by two ovoid swellings (bulbs), either contiguous or separated, and a large terminal bulb. The tear-shaped terminal bulb larger in diameter than the stem or proximal bulbs, with the acuminate end posteriad and upturned dorsally, and bears multiple filaments and bulblets in two groups, one at its anterodorsal surface and one at its terminus. Barbel relatively short ( $\leq 20 \% \mathrm{SL})$.

Description.- - Head and body black and scaleless (Fig. 2A), without patches of lighter pigmentation or subcutaneous pigment spots. Lateral photophores evenly spaced, not in pairs; small photophores over most of body and head. Anterior margin of fleshy orbit without a photophore-bearing pedicel. Fin-ray elements dark, covered with transparent membrane, the latter studded with small putatively luminescent bodies. Anal-fin base about twice as long as dorsalfin base. Cleft of mouth straight, upper jaw protractile.

Basic barbel morphology established by 46 mm SL, well before sexual maturity (about 120 $\mathrm{mm}$ ), without obvious sexual dimorphism. Barbel proportions established by about $65 \mathrm{~mm} \mathrm{SL}$. Barbel main stem length (BL) relatively short (14-21\% SL). In all specimens, external pigmentation of barbel stem limited to stem base and to a ventral row of spots and/or ocelli from origin to branching point. Internal core of main stem between origin and terminal bulb darkly pigmented. Between branching point and terminal bulb, bands of colorless reflective material encircle main stem core. Main stem with two large (about $20-25 \%$ BL combined) proximal bulbs, either contiguous or separate; when proximal bulbs separate, internal core between bulbs pigmented. Main stem distal of proximal bulbs thick, progressively enlarged distad, short (about 15\% BL), and curved ventrally to accommodate large terminal bulb (about 20-30\% BL). Terminal bulb diameter twice that of main stem and greater than or equal to that of any proximal bulbs; terminal bulb prolate spheroidal, with an up-turned, acuminate terminus; terminal bulb with two distinct groups of short filaments with bulblets, one group on its anterodorsal surface and one group at it terminus (Figs. 1A, 2B); terminal bulb asymmetrically positioned about main axis, with half its diameter dorsal to main stem.

Barbel with three branches arising together from main stem, from before midlength (28$45 \% \mathrm{BL}$ ). All branches internally and externally 

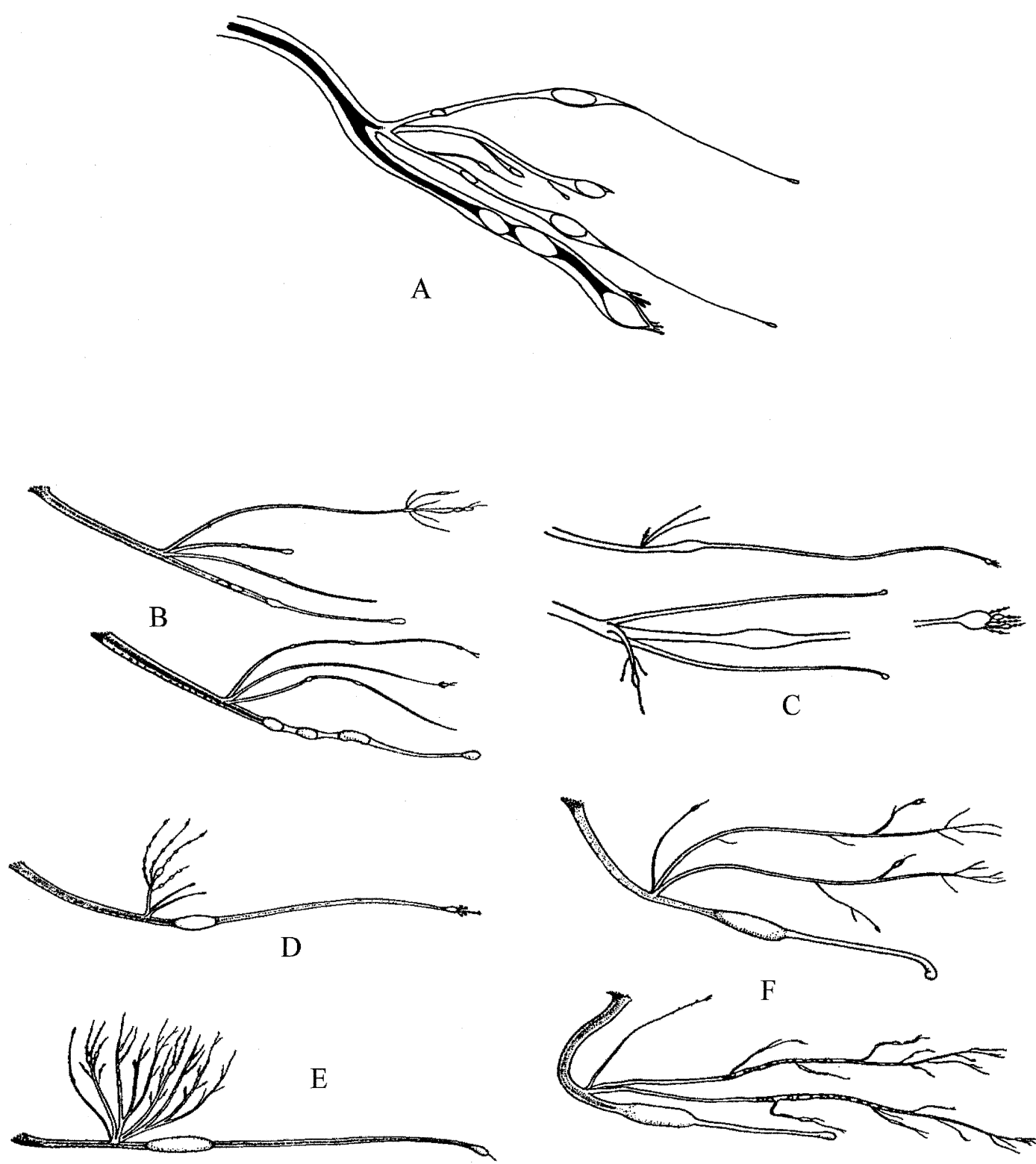

Fig. 1. Barbels of species of Eustomias (Neostomias). (A) Eustomias jimcraddocki; (B) Eustomias tetranema; (CE) Eustomias filifer, (F) Eustomias monodactylus. A, drawn by T. Sutton, B-F, after Regan and Trewavas (1930).

unpigmented; length of branches from 50$100 \% \mathrm{BL}$; branches with at least one bulb, in most cases three (a small proximal bulb, a large median bulb [approximately equal in size to main stem proximal bulbs], and a minute bulb at tip). In all specimens, side branches with secondary branch with a single minute bulb. In many specimens median branch bulb also with secondary branch with a single bulb. All barbel bulbs, including those on branches, bright violet in freshly caught holotype, except for first proximal bulb, which was dark purple.
In males, postorbital organs (PO) about twice diameter of those of females and immature specimens (12-13\% of head length vs $5-6 \%$, respectively). PO of freshly caught holotype (む) bright white and opaque.

Holotype (paratypes): D 24 (24-25); A 41 (40-41); $\mathrm{P}_{1} 1$ + rudiment (all); $\mathrm{P}_{2} 7$ (all). Photophores: BR 10 (10-11), IP 7 (all), PV 26 (2328), VAV 14 (13-15), OV 27 (26-28), VAL 14 (11-15), AC 20 (20-22). Premaxillary teeth: on left side 9 (7-10), tooth number 3 and 5 [outer row] fixed, all others [inner row] depressible; 


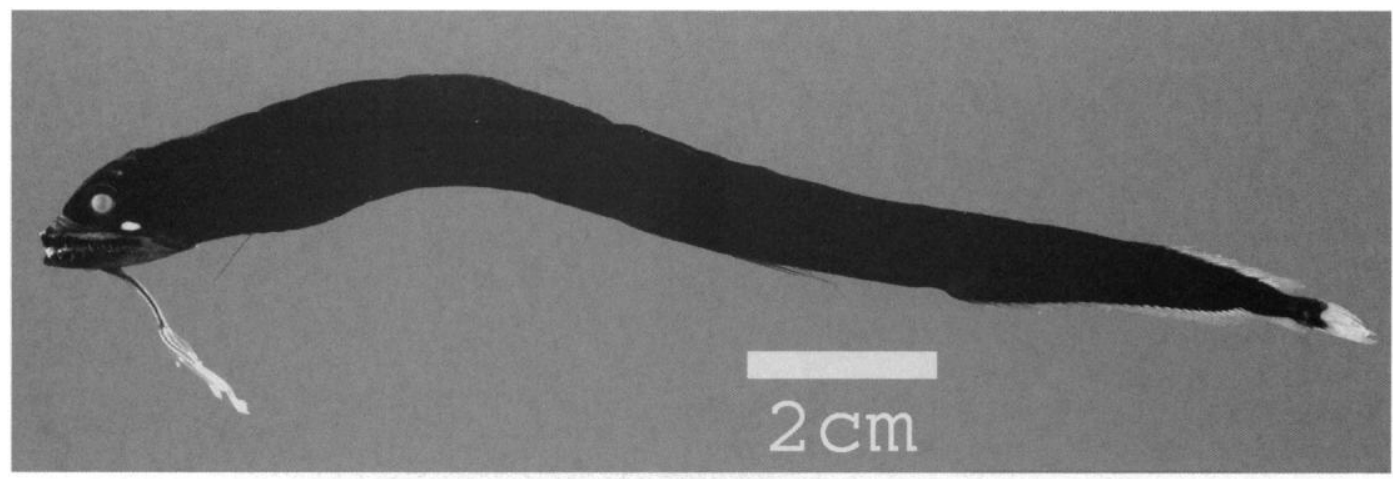

A

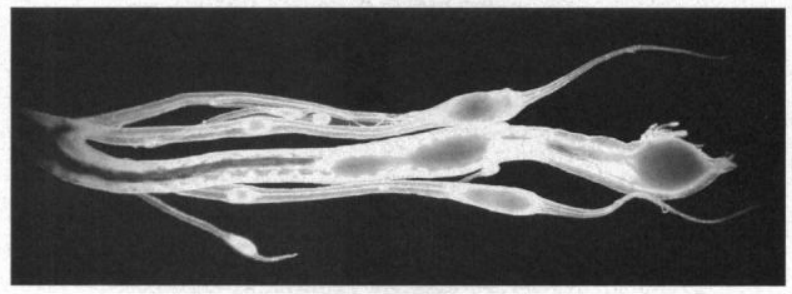

B

Fig. 2. (A) Eustomias jimcraddocki, n. sp., holotype, MCZ 162290, $142 \mathrm{~mm}$ SL. (B) Close-up of the distal half of the barbel of Eustomias jimcraddocki.

on right side 7 (7-10); number 2 longest (number 5 as long as 2 in some paratypes). Maxilla with small serrae (all). Mandibular teeth: on left side $9(6-12)$, numbers 3 and 7 [outer row] fixed, all others [inner row] depressible; on right side 8 (8-12); number 2 longest (number 3,4 , or 6 longest in some paratypes). Three groups of teeth, 2-4 teeth per group, on basibranchials. Vertebrae (based on the holotype and two paratypes, USNM 323066 and MCZ 162851): first two vertebral centra undeveloped, notochord bending to form a ventrally convex loop bearing an isolated centrum; behind this a gap of about 2.5 anterior centra, followed by 60 (60-61) well-developed centra, not counting urostyle. Anus immediately before anal origin, between VAV 9-10 (9-11). Ventral groove extending from isthmus to PV 9 (9-12).

Measurements in percent SL: body long, slender, greatest depth just behind head 8.7 (6.1$8.2)$; predorsal length 85.2 (84.7-88.6); preanal length 72.5 (70.5-78.4); prepelvic length 53.5 (50.9-59.1); caudal peduncle depth 1.7 (1.62.5); head length [HL] 12.3 (12.1-14.6); barbel stem length 14.7 (13.7-20.7); length of dorsalfin base 12.0 (10.9-13.2); length of anal-fin base 25.8 (21.9-25.7). Measurements in percent HL: snout to anterior margin of fleshy orbit 34.9 (30.9-51.0, with range derived from variability in premaxillary protrusion); fleshy orbit diameter 24.6 (16.7-22.5); bulb of PO 12.0 ( $\delta: 12.1-$
13.6; $q$ and immature: 4.6-6.4); upper jaw length 84.6 (81.1-96.0). Measurements in percent BL: barbel length to first branches 44.5 (28.2-45.1); length of longest branch of barbel 73.2 (47.1-100); length of proximal bulbs on main stem $15.5(9.3-26.7)$; length of terminal bulb 8.0 (7.9-17.6); main stem distance between last proximate bulb and terminal bulb 18.7 (19.5-28.7). Note: proximal bulb length combined if contiguous; largest was measured if separate.

Remarks. - Regan and Trewavas (1930) provided characters for 10 subgenera of Eustomias, later revised by Gibbs et al. (1983) and Gomon and Gibbs (1985) to nine. The possession of a single well-developed pectoral ray (plus one rudimentary ray) and the characters of the barbel place E. jimcraddocki in the subgenus Neostomias Gilchrist, with two other currently recognized species, E. tetranema Zugmayer, 1913, and E. filifer (Gilchrist, 1906). Eustomias tetranema is known from the North Atlantic east of $45^{\circ} \mathrm{W}$, between $32^{\circ}$ and $38^{\circ} \mathrm{N}$, with one record from the South Atlantic at $18^{\circ} \mathrm{S} 29^{\circ} \mathrm{W}$ (Gibbs and Barnett, 1990). Eustomias filifer is known from the North and South Atlantic and the Gulf of Mexico (Gibbs and Barnett, 1990; Sutton and Hopkins, 1996).

Regan and Trewavas (1930) described two additional species of Neostomias, Eustomias ramulo- 


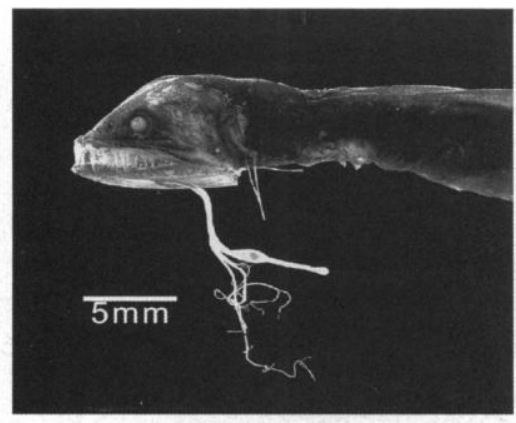

A

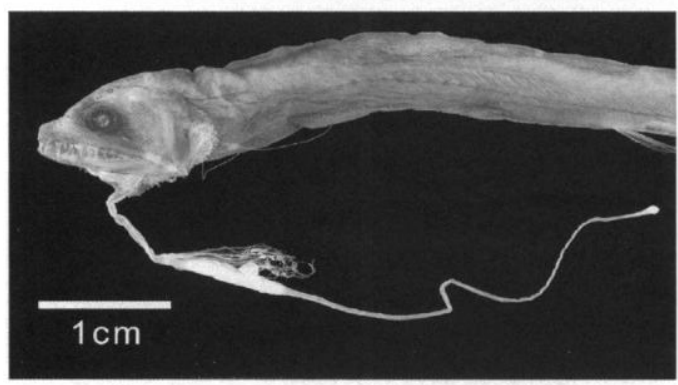

B

Fig. 3. (A) Eustomias monodactylus, MCZ 53246, 92 mm SL. (B) Eustomias filifer, MCZ 96144, $90 \mathrm{~mm}$ SL.

sus and E. monodactylus, based on one and two specimens, respectively. The taxonomic status of these species has fluctuated. Morrow and Gibbs (1964) placed both in synonymy with $E$. filifer, citing that the variation in the barbel branches was sufficient to cast doubt on their validity and concluded that the three forms were conspecifics. It is noted here that their conclusion was drawn without examining specimens. Gibbs (1986), in a treatise on the oceanic species concept, resurrected E. monodactylus, ostensibly after an examination of additional material. Incidentally, in that same work, Gibbs made reference to a related but undescribed species from off Bermuda, which is in fact the species described here. Gibbs and Barnett (1990) later again placed $E$. monodactylus in synonymy with E. filifer without comment. After reviewing additional material of the above species, we found that E. monodactylus and E. filifer differ consistently in barbel structure, and we, therefore, restore the species status of $E$. monodactylus. Briefly, E. filifer has a barbel at least twice as long as E. monodactylus, with branches half as long, relative to SL and BL, respectively (Figs. $1 \mathrm{E}-\mathrm{F}, 3$ ). We also found differences in barbel branch structure between E. ramulosus and E. filifer, but, without examining the types of each, we accept their synonymy.

Eustomias jimcraddocki can be distinguished from its consubgenerics by its barbel characteristics, particularly with regard to the proximal and terminal bulbs. In the presence of multiple bulbs on the main stem proximal to the terminal bulb, E. jimcraddocki resembles only E. tetranema, all other species having only one well-defined bulb. Eustomias jimcraddocki can be distinguished from $E$. tetranema by the large, filamented terminal bulb (vs simple and small in the latter), the shorter barbel (14-21\% SL vs $36-45 \%$, respectively), and the close proximity of the terminal bulb and the last proximal bulb (1-2 bulb diameters vs 10-13). In addition, the stem beyond the last proximal bulb tapers distally in E. tetranema, whereas it thickens distally in E. jimcraddocki. In specimens with two contiguous proximal bulbs that might appear as one, E. jimcraddocki most resembles E. monodactylus (the main stem proximal and terminal bulbs of E. filifer are at least 6-17 bulb diameters apart) and can be distinguished from $E$. monodactylus again by its large, filamented terminal bulb.

Distribution.-Eustomias jimcraddocki is known only from the western North Atlantic Ocean, between $40^{\circ} 22^{\prime} \mathrm{N}$ (Slope Water south of Georges Bank; see Moore et al., 2003) and $26^{\circ} 35^{\prime} \mathrm{N}$ (Northern Sargasso Sea). Discrete depth captures suggest some form of vertical migration from below $500 \mathrm{~m}$ during the day to within the upper $100 \mathrm{~m}$ at night.

Etymology.-This species is named in honor of Dr. James E. Craddock of the Woods Hole Oceanographic Institution in recognition of his many contributions to our knowledge of deepsea fishes.

Comparative material.-Eustomias filifer MCZ 42286 (?, 101), $39^{\circ} 20^{\prime} \mathrm{N} 70^{\circ} 41^{\prime} \mathrm{W}, 20$ September 1962, time, $82 \mathrm{~m}$; MCZ 56672 (?, 83), $40^{\circ} 00^{\prime} \mathrm{N}$ $66^{\circ} 20^{\prime} \mathrm{W}, 17$ September 1962, $51 \mathrm{~m}$; MCZ 96142 (?, 71), $33^{\circ} 51^{\prime} \mathrm{N} 74^{\circ} 33^{\prime} \mathrm{W}, 14$ August 1978, 1010 $700 \mathrm{~m}$, MOC10; MCZ 96143 (?, 68), $28^{\circ} 23^{\prime} \mathrm{N}$ $67^{\circ} 33^{\prime} \mathrm{W}, 08$ December 1968, 530-570 m; MCZ 96144 (?, 90 ), $08^{\circ} 58^{\prime} \mathrm{N} 53^{\circ} 10^{\prime} \mathrm{W}, 25$ September 1973, 475-480 m; MCZ 96145 (?, 2: 62-63), $33^{\circ} 15^{\prime} \mathrm{S} 39^{\circ} 01^{\prime} \mathrm{W}, 7$ April 1971, 175-195 m; MCZ 96167 (?, 102) $27^{\circ} 11^{\prime} \mathrm{N} 43^{\circ} 46^{\prime} \mathrm{W}, 05$ December 1970, 85-90 m; MCZ 153128 (?, 2: 75-88), $32^{\circ} 02^{\prime} \mathrm{N} 64^{\circ} 09^{\prime} \mathrm{W}, 16$ November $1992,100-200$ m. MCZ 162130 (?, 67), $40^{\circ} 15^{\prime} \mathrm{N} 68^{\circ} 08^{\prime} \mathrm{W}, 19$ July 2002, 0-915 m, IYGPT; USNM 263091 (?, 148), $32^{\circ} 09^{\prime} \mathrm{N} 64^{\circ} 11^{\prime} \mathrm{W}, 24$ August 1971, 0-750 $\mathrm{m}$, IKMT; USNM 322893 (?, 82), $0800^{\prime} \mathrm{N}$ $4800^{\prime} \mathrm{W}$, 22 January 1969, $130 \mathrm{~m}$; USNM 322962 (?, 73), $37^{\circ} 44^{\prime} \mathrm{N} 70^{\circ} 14^{\prime} \mathrm{W}, 03$ December 1968, 0 $200 \mathrm{~m}, 1-\mathrm{m}$ net. Eustomias monodactylus MCZ 
53246 (ㅇ?, 92), $35^{\circ} 28^{\prime} \mathrm{N} 61^{\circ} 13^{\prime} \mathrm{W}, 26 \mathrm{March}$ 1974, 2030-2325 h, 980-990 m; MCZ 56679 (?, $57), 35^{\circ} 43^{\prime} \mathrm{N} 67^{\circ} 21^{\prime} \mathrm{W}, 30$ October 1977,1000 $1820 \mathrm{~m}$, MOC10; MCZ 70440 (?, 95), $33^{\circ} 58^{\prime} \mathrm{N}$ $74^{\circ} 42^{\prime} \mathrm{W}, 14$ August 1978, 700-1190 m, MOC10; MCZ 97813, (?, 70), WHK6720, no data. MCZ 101638 (?, 145), $31^{\circ} 45^{\prime} \mathrm{N} 64^{\circ} 15^{\prime} \mathrm{W}, 13 \mathrm{June} 1992$, 500-250 m; USNM $322963(\%, 207), 33^{\circ} 01^{\prime} \mathrm{N}$ $39^{\circ} 34^{\prime} \mathrm{W}, 27$ April 1979, 1940-2027 h, 0-185 m; USNM 263073 (?, 114), 32 $26^{\prime} \mathrm{N} 64^{\circ} 10^{\prime} \mathrm{W}, 22$ August 1971, 0-575 m, IKMT; USNM 263083 (?, 66), 3222' N 6404' W, 22 August 1971, 0-100 m, IKMT. Eustomias tetranema USNM 323403 (?, 87),

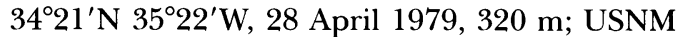
372724 (?, 123), AD323/79, Sargasso Sea, 1979; USNM 372725 (?, 136), AD338/79, Sargasso Sea, 1979. USNM uncat. (?, 2: 84-111), AD 339/ 79, Sargasso Sea, 1979.

\section{ACKNOWLEDGMENTS}

We are grateful to the NOAA Ocean Exploration program; M. Vecchione; J. K. Galbraith for rigging the trawls; C. Kenaley for radiographs and digital images, as well as for providing invaluable assistance in all phases of this study; J. Moore, S. Henley, R. Gibbons, and P. Chase for excellent shipboard assistance. For facilitating our visit to the USNM, we thank $\mathbf{R}$. Vari, S. Jewett, S. Reardon, and L. Palmer. We also thank J. Craddock and T. Pietsch for critically reading the manuscript. Several grants from National Science Foundation allowed the transfer and databasing of the MCZ collection, thereby making this study material available. TTS was supported in part by the Ocean Life Institute, Woods Hole Oceanographic Institution. This is Contribution 10916 from the Woods Hole Oceanographic Institution.

\section{Literature Cited}

GIBbs JR., R. H. 1971. Notes on fishes of the genus Eustomias (Stomiatoidei, Melanostomiatidae) in
Bermuda waters, with the description of a new species. Proc. Biol. Soc. Wash. 84:235-244.

1986. The stomioid fish genus Eustomias and the oceanic species concept, p. 98-103. In: Pelagic biogeography. UNESCO Tech. Paper 49, Paris.

$\longrightarrow$, AND M. F. BARnETT. 1990. Melanostomiidae, p. 308-337. In: Check-list of fishes of the eastern tropical Atlantic. J.-C. Quéro, J.-C. Hureau, C. Karrer, A. Post, and L. Saldanha (eds.).UNESCO, Paris.

- AND C. KARNELlA. 1987. Biology of midwater fishes of the Bermuda Ocean Acre. Background and methods used in studies of the biology of fishes of the Bermuda Ocean Acre. Smiths. Contrib. Zool. 452:3.

, T. A. Clarke, And J. R. Gomon. 1983. Taxonomy and distribution of the stomioid fish genus Eustomias (Melanostomiidae), I. Subgenus Nominostomias. Ibid. 380:1-139.

Gomon, J. R., AND R. H. GibBs JR. 1985. Taxonomy and distribution of the stomioid fish genus Eustomias (Melanostomiidae), II. Biradiostomias, new subgenus. Ibid. 409:1-58.

Moore, J. A., K. E. Hartel, J. E. Craddock, And J. K. GALBRAITH. 2003. An annotated list of deepwater fishes from off the New England Region, with new area records. Northeastern Nat. 10:159-248.

Morrow JR., J. E., AND R. H. GibBS JR. 1964. Family Melanostomiatidae, p. 351-511. In: Fishes of the Western North Atlantic. Mem. Sears. Fdn. Mar. Res. 1, New Haven, CT.

Regan, C. T., AND E. Trewavas. 1930. The fishes of the families Stomiatidae and Malacosteidae. Dana Rep. 6:1-143.

SutTon, T. T., AND T. L. Hopkins. 1996. Species composition, abundance and vertical distribution of the stomiid (Pisces: Stomiiformes) fish assemblage of the Gulf of Mexico. Bull. Mar. Sci. 59:530-542.

(TS) HARBor BRANCH OCEANOGRAPHIC INSTITUTION, Division OF MARINE SCIENCE, 1500 US 1 N, Fort PIERce, Florida 34946; AND (KEH) Museum of Comparative ZoOlogy, Harvard University, Cambridge, MassachUSETS 02138. E-mail: (TS) tsutton@hboi.edu. Send reprint requests to TS. Submitted: 9 May 2003. Accepted: 15 Sept. 2003. Section editor: D. G. Buth. 